\title{
Miranda
}

Revue pluridisciplinaire du monde anglophone /

Multidisciplinary peer-reviewed journal on the English-

speaking world

13 | 2016

Thomas Spence and his Legacy: Bicentennial

Perspectives

\section{Jean-Stéphane Messiani, Les Journaux de voyage de James Cook dans le Pacifique}

Colette Selles

\section{(2) OpenEdition}

\section{Journals}

\section{Electronic version}

URL: http://journals.openedition.org/miranda/9259

DOI: $10.4000 /$ miranda.9259

ISSN: 2108-6559

\section{Publisher}

Université Toulouse - Jean Jaurès

\section{Electronic reference}

Colette Selles, "Jean-Stéphane Messiani, Les Journaux de voyage de James Cook dans le Pacifique", Miranda [Online], 13 | 2016, Online since 25 November 2016, connection on 16 February 2021. URL: http://journals.openedition.org/miranda/9259 ; DOI: https://doi.org/10.4000/miranda.9259

This text was automatically generated on 16 February 2021

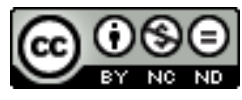

Miranda is licensed under a Creative Commons Attribution-NonCommercial-NoDerivatives 4.0 International License. 


\title{
Jean-Stéphane Messiani, Les Journaux de voyage de James Cook dans le Pacifique
}

\author{
Colette Selles
}

\section{REFERENCES}

Jean-Stéphane Messiani, Les Journaux de voyage de James Cook dans le Pacifique. Du parcours au discours (Collection "Textuelles », Aix-en-Provence : Presses Universitaires de France, 2015), 25 euros, 316 p, ISBN 978-2-85399-978-6

1 Jean-Stéphane Massiani's work offers an exhaustive study of Cook's Journals. The introduction situates the Journals in their geopolitical and cultural context, in the Age of Enlightenment, notably with the notion of the Noble Savage. It underlines that the book will examine the Journals and their relationship with travel literature-a genre analysed by Jean Viviès- as well as the relationships between Cook's Journals and the versions published by the Admiralty.

2 The first part "L'Océan, l'Homme et les Voyages" is devoted to the history of the quest of "Terra Australis Incognita" and to Captain Cook, mentioning his education, his journey in life from his apprenticeship as a sailor to his position as captain. It hints at the different facets of the man and highlights his missions that were of prime importance: on the Endeavour Cook was meant to observe the transit of Venus and sailed along the eastern coast of what was to be called Australia; on the second voyage his mission consisted in exploring the Antarctic area, and on the third in trying to find the North West passage. The author gives a very detailed analysis of Cook's version in his journals and his revisions. Besides, the text emphasizes the requests of the Admiralty: geographical and topographical elements, the fauna and flora, the behaviour towards the natives. The text underlines the dichotomy between the friendly behaviour towards the natives that is recommended and the fact that they are dispossessed of their land. 
The author highlights the near similarity between the Admiralty and the Royal Society: if the former refers to the English as "the first discoverer and possessor" of the place (58), the latter regards the natives as the possessors of their land but that they are meant to be "submitted" (59). Besides, the text emphasizes the scientific interests of The Royal Society in the soil, animals, the languages...

The second part, "Présentation des journaux et problématique du texte", offers a detailed analysis of Cook's Journals, even paying attention to spelling and underlines Cook's own evolution as a captain and writer. It examines how the journals are organized around the three voyages between time spent onshore-with descriptions of natural elements, of his encounters with natives and of their languages too-and at sea with descriptions of life on board and of scientific elements such as longitude and latitude or winds. Moreover the author examines the manuscripts of Captain Cook's three voyages and shows how they differ. For instance, the first one and its four manuscripts, Canberra, Mitchell, Greenwich, and Admiralty offer similarities especially with descriptions of Tahiti with Cook and Joseph Banks, the botanist, and reports about the Great Barrier Reef. Differences are pinpointed, and they are sometimes shown as deriving from Cook's determination to protect his men and his own status as seen with the report of the killing of a young Maori. The different manuscripts of the second voyage are also closely examined, and underline the part played by William Wales, the astronomer, and William Dawson. Emphasis is laid on the interest in the areas visited on the expedition as underlined by notes on the languages spoken in Tahiti, New Zealand, The New Hebrides, and maps.

4 Part three "Le récit-documentaire" dwells on navigation: currents, winds and tides. It also offers advice to sailors on the Great Barrier Reef or Cape Horn and their dangers, for instance. Life on board is dealt with too, with a certain amount of equality recommended between the men and attention paid to hygiene and diet, a very important element. Cook also dwells on the sights a sailor can benefit from: the beauty of nature, its impressive quality, notably the icebergs that strike a "sublime" (99) note. The description of Tahiti is very detailed too: not only the place but the natives' customs (cannibalism for some) and religious practices are examined. What the author insists on is also the fact that Cook dwells on elements that, from his point of view, England could profit from. Besides, this part underlines that Cook thought that there was no southern continent and that there might be what was called the North-West passage but that navigation was impossible.

5 Besides, this part is also concerned with ethnology. Cook dwells on descriptions of the natives in the Pacific, seen through the eyes of an Englishman, and therefore graded according to the standards of beauty of his native country. The people from The New Hebrides are thus compared to monkeys whereas the natives from the Marquises are seen in a more favourable light. Jean-Stéphane Massiani underlines the "subjectivity" of these judgments, the difficulty of understanding the Other, his customs and beliefs, in particular because of the language barrier. The author situates these views of the Other in the context of the $18^{\text {th }}$ century and the notion of the Noble Savage. He analyses Cook's vision of these distant places in this light and stresses the duality: Tahiti is a paradise, but there are cases of human and children's sacrifices, and anthropophagy in New Zealand.

6 Cook's knowledge of mathematics, hydrography and astronomy is highlighted. His journals testify to a wide range of scientific interests: a lunar eclipse, icebergs, fauna 
and flora, animals (kangaroos, for instance), how to assess longitude-which was an important step forward-and the diet on his ship, notably with fruit, vegetables, and sauerkraut against scurvy that saved many lives and for which he was awarded the Copley medal by the Royal Society in 1776.

Part Four: «Entre littéralité et littérarité : la dimension rhétorique des journaux de Cook ».

8 «Dire le Monde »: this section questions how to capture the real in words, the gap that may exist between the world and words. Painting-however limited it may be-seems somehow to compensate what words cannot express. In beautiful pages the author develops the metaphor of the book which represents the world, and allows it to be seen, or the painting metaphor. Combined with the borrowing of native words and comparisons, these strategies are shown as aiming at rendering an unfamiliar world.

In "Stratégies narratives" the author examines how Cook's Journals could be read as literary texts, notably by referring to Genette's definitions: chronological order, rhythm, frequency, mode and voice (185). Focalisation, the choice of the narrative voice, the picaresque, suspense are some of the devices used to attract the reader. This section is remarkable for its rich references not only to Genette, but Bakhtine, and also Todorov who explained that at the time the "civilized world" was the white man's world" (201). In fact, two kinds of attitude towards the natives seem to be combined in Cook who was friendly but had the white man's sense of superiority.

Moreover, intertextuality is an important element in the Journals, such as when Cook uses Captain Furneaux's journal, or others' writings, Wales's or Banks's, and in his descriptions of the fauna and flora. However, what is underlined is that Cook still offers his own version.

11 Part Five : « Du Journal de bord à la relation publiée : parcours d'un texte »

12 This part is devoted to the different authors of the official versions of Cook's Journals, John Hawkesworth and John Douglas, chosen by the Admiralty. It dwells on the similarities and differences between them and between Cook's writings and theirs. What is emphasized with Hawkesworth's version is the defence of Britain's hegemony in the Pacific which was of utmost importance from political, geopolitical, and economic points of view. This standpoint was shared by John Douglas who, as a clergyman, also insisted on Britain's civilising mission. For example, a divergence from Cook's position is introduced: whereas Cook questioned the benefits the natives might derive from the encounter with Europeans (290), Douglas insisted on the part played by "Providence in bringing the benefits of civilization" to these people.

13 The book ends on a very stimulating conclusion. It insists on the duality of Cook's Journals which combine elements of travel narrative with literary creation, interrogating the status of the real presented in the Journals and based on description and construction (293). It also develops Cook's literary heritage, notably Coleridge's The Rime of the Ancient Mariner. Besides, a very detailed bibliography testifies to the wide scope of Jean-Stéphane Massiani's work.

14 Jean-Stéphane Massiani's book is of utmost interest for scholars and students specializing in travel and exploration literature. It offers a very detailed and thorough analysis covering many fields (intertextuality, "littérarité"," littéralité", ethnology...). It may also be of interest to readers who are not specialists of this field, but can appreciate an in-depth analysis of such an important stage in the history of the world. 


\section{INDEX}

Keywords: Cook's journals, the Admiralty, four manuscripts, the Royal Society, Tahiti, New Zealand, Terra Australis incognita, the Endeavour, the transit of Venus, the Great Barrier Reef, longitude and latitude, astronomy, winds, navigation, diet (sauerkraut) geography and topography, maps, fauna and flora, languages, customs, natives, cannibalism, the Noble Savage, the world and words, travel narrative, literary creation, intertextuality, ethnology, England's civilising mission, England's hegemony

Mots-clés: les journaux de Cook, l'Amirauté, quatre manuscrits, la Société Royale, Royal Society, Tahiti, Nouvelle Zélande, Terra Australis Incognita, l'Endeavour, le transit de Venus, la Grande Barrière de Corail, longitude et latitude, astronomie, vents, navigation, régime alimentaire (choucroute), géographie et topographie, cartes, faune et flore, langues, coutumes, autochtones, cannibalisme, le Bon Sauvage, le monde et les mots, récit de voyage, création littéraire, intertextualité, ethnologie, la mission civilisatrice de l'Angleterre, l'hégémonie anglaise

\section{AUTHORS}

\section{COLETTE SELLES}

Maître de conférences honoraire

Université de Toulouse - Jean Jaurès

colette.selles@wanadoo.fr 